\title{
Influence of Manager Ownership, Manager Quality and Conservatism on Earnings Quality: Evidence from Indonesian Banking Sector
}

Fazril Azi Nugraha*, Erna Setiany

Universitas Mercubuana Jakarta, Indonesia

DOI: $10.36348 / \mathrm{sb} .2020 . \mathrm{v} 06 \mathrm{i} 03.004$

| Received: 19.03.2020 | Accepted: 26.03.2020 | Published: 30.03.2020

*Corresponding author: Fazril Azi Nugraha

\section{Abstract}

This study aims to look at the effect of manager ownership, manager quality, and conservatism on earnings quality in banking companies in Indonesia. The population used in this study is banking companies listed on the Indonesian stock exchange. The sample used was 41 banking companies on the Indonesia Stock Exchange in the period 2013-2018. Purposive sampling is used in this study, based on sampling criteria, the number of observations was 218 unit of analysis. The results of the study found that manager ownership has a positive and significant effect on the quality of accrual earnings in companies in the banking sector, while manager quality and conservatism do not have a significant effect on quality accrual earnings in a sample of banking sector companies in Indonesia.

Keywords: Banking Sector, Conservatism, Discretionary Accrual, Earning Quality, Free Cash Flow, Leverage, Managerial Ownership, Manager Quality, Sales Growth.

Copyright @ 2020: This is an open-access article distributed under the terms of the Creative Commons Attribution license which permits unrestricted use, distribution, and reproduction in any medium for non-commercial use (NonCommercial, or CC-BY-NC) provided the original author and source are credited.

\section{INTRODUCTION}

The management makes financial statements as a tool to provide financial information to stakeholders including government, investors, creditors, and other parties. The financial statement information is carried out to meet the information needs of internal and external stakeholders as the responsibility of management. So that the report becomes a compulsory source of information to be published and is a means of management accountability towards the management of the resources owned by investors and creditors. According to Scott [1] Agency theory is a branch of game theory to understand and learn how to design contracts in order to motivate the minds of agents to act in accordance with the wishes of the principal when there is a conflict of interest between the agent and the principal. Many studies that try to explain the relationship between owners and managers and also distrust of the performance of managers as representatives of the owner are called agency problems in agency theory. For one thing, management often has great economic motivation to increase added value for itself for two reasons. First, compensation for management is related to financial performance. Then the second, incentives related to job prospects (position). Good performance in companies tends to get promotions. Managers who can achieve the objectives of the shareholders will get a better offer opportunity on the job market ie high salaries [2]. To get these incentives, one of them is through earnings management. Agency theory is important to explain the phenomenon that occurs in managers in reporting corporate earnings or earnings management, causing differences in the quality of earnings generated in the report due to operational cycles and decision making by managers. In this case, corporate governance is one solution to reduce conflicts of interest. According to Bloomfield [2], corporate governance becomes a system to direct or control a company by determining rights and responsibilities between the board, managers, shareholders. Then outline the rules and procedures for making decisions in the company. So that governance can be a mechanism to resolve conflicts of interest. Wherewith the governance can improve the quality of earnings by ensuring that reported income is not made up for a specific purpose.

Previous research on earnings management in banks in Indonesia was carried out by Muid [3] and Abbas [4] with accrual discretion used to calculate earnings management carried out in banks in Indonesia. While Faradilla [5] examines Islamic banking in 
Indonesia. In this study, from various indicators of earnings quality, researchers use discretionary accruals as the dependent variable where the higher the value of discretionary accruals then we will look for the influence of manager ownership, manager quality and conservatism.

Ownership in companies can be owned by individuals or corporations so that company managers or directors can become shareholders. Furthermore, Putra [6] describes governance mechanisms that can be used to align activities to suit the interests of company owners by involving managers in company ownership. With ownership, the manager can improve integrity in reporting. So companies with a higher percentage of managerial ownership, have a tendency to be more responsible in managing the company, are better in making decisions, and report financial statements correctly and honestly so that they have high integrity in the financial statements. Furthermore, Susanti [7] states that managerial ownership can align the interests of agents and principals where the manager will get benefits and losses directly from the decisions taken. Based on several previous studies the quality of earnings is influenced by manager ownership, where manager ownership is one of the elements of corporate governance. Managers report profit opportunistically to maximize their personal interests, making the quality of their profits low [8]. Setiany [9] found that better corporate governance, the higher the level of transparency, thereby increasing its financial performance. Siallagan et al. [10] Found that managerial ownership has a positive influence on earnings quality, Muhammad [11] said governance mechanisms provide monitoring or oversight of financial reporting so that managerial ownership positively influences the earnings quality of the company. Subsequent research Asri [12] found that managerial ownership did not have a significant positive effect on earnings quality due to low managerial ownership. Wafa [13] found manager ownership will affect earnings quality if manager ownership is high. Hypothesis 1: Manager ownership has a positive influence on earnings quality

The company has a goal to increase the value of shareholders which is reflected by high profits. The company's performance in making profits is very much influenced by managerial who acts as the decisionmaker and determinant of the company's strategy, the ability of managers to manage the company's resources is very important to bring profit to the company. Quality managers provide satisfactory performance for stakeholders by managing resources effectively and efficiently. Qualified managers are managers who are able to efficiently use company resources, namely all the use of innovative capital, labor and assets to generate profits.
Demerjian [14] also said that highly capable managers use their superior skills to report income streams to avoid various pitfalls in reporting that can harm shareholders so that earnings management can benefit shareholders because intentional income smoothing can be seen as a profitable activity by managers. Setin and Etty [15] find that more capable managers are involved in earnings management which leads to their valuable reputation, so they create incentives to avoid overly high-income management. In addition, managers tend to be involved in earnings management and rely more on accrual earnings management. Weitzu and Chia [16] found that managerial ability has a key role in the process of preparing financial statements and is influenced by IFRS, which can effectively improve overall information quality. Adoption of discretionary accruals, there is the possibility of opportunism and increasing the value of information. Meca and Sanchez [17] found that managerial ability plays an important role in forming financial statements. Hypothesis 2: Manager quality negatively influences earnings quality.

Conservatism is a concept in which delayed recognition of future cash inflows is carried out. In conservative accounting where the accountant will report financial information at the lowest position of several possible items, namely on assets and income, while at the highest for liability and expense items [12]. The banking sector in Indonesia every company is overseen by the Financial Services Authority (OJK) and the central bank, namely the Indonesian bank. One way is to regulate the health of banking, in maintaining and monitoring the level of the healthy of the company is the responsibility of the directors and the board of commissioners. Sofiasani and Gautama [18] CAMEL ratio as an assessment of several aspects that affect the condition and performance of a bank through several factors namely capital, asset quality, management, profitability, liquidity. Also, according to Harnovinsah [19], when a company is capable and looks good in financing its activities such as operations, investment, and funding. Stakeholders will rate the performance of management well as they can regulate the company's financial condition.Previous research on conservatism Veronica [20], Vatanparast [21], Tuwentina and Wirama [22] show that accounting conservatism has a significant and positive influence on earnings quality. This shows that conservative companies will get a positive response from investors, this is based on the quality of the value of earnings contained in the financial statements. Besides conservatism can improve earnings quality and reduce conflicts between investors and management. So conservatism becomes recommended to managers to adopt several conservative approaches in recognizing income and costs so that reported earnings have higher quality. Hypothesis 3: Conservatism has a positive effect on earnings quality. 


\section{RESEARCH METHODE}

The population in this study is a banking sector company that listed in Indonesia Stock Exchange consisting of 41 companies from 2013-2018 (6 years). There were 232 observational data in the study, but there were 14 outlier data, so the number of sample data in this study becomes 218 observations.

This research is quantitative research which prioritizes theory testing through the measurement of variables in the numbers form, The study also emphasizes the causal effect, which is to explain phenome in the effect of the independent variables on the dependent variable. SPSS version 25 program is using to processed data.

The earnings quality proxied by discretionary accruals that occur when there are differences between the time of capital flow and the time to audit income or profit and also as a measurement in accrual earnings management. The study uses Modified Jones's model as earning quality proxy with the following formula:

$$
\begin{array}{ll}
\mathrm{DACC} & =\mathrm{TACC}-\mathrm{NDAC} \\
\mathrm{NDAC} & =\alpha_{1} \frac{1}{\mathrm{~A}_{\mathrm{t}-1}}+\alpha_{2}\left(\triangle \mathrm{REV}_{\mathrm{t}}-\triangle \mathrm{REC}_{\mathrm{t}}\right)+\alpha_{3} P P E_{t} \\
\mathrm{TACC} & =\alpha_{1} \frac{1}{\mathrm{~A}_{\mathrm{t}-1}}+\alpha_{2}\left(\Delta \mathrm{REV}_{\mathrm{t}}-\Delta \mathrm{REC}_{\mathrm{t}}\right)+\alpha_{3} P P E_{t}+e
\end{array}
$$

TACC or total accrual is net income operation cash flow, NDA is Non-discretionary Accrual, At- 1 is total assets in previous, $\triangle \mathrm{REV}$ is total income in the year $\mathrm{t}$ - total income from previous years, $\triangle \mathrm{REC}$ is the receivables in the year $\mathrm{t}$ - receivables from previous years and PPEt is fixed assets, $\mathrm{e}$ is Discretionary Accruals, the higher value of $e$ (discretionary accruals) that means more earnings management that means a decline in the quality of the company's earnings reports.

Furthermore, managerial ownership is proxied by the number of shareholders ownership by the manager/director used to see the percentage of ownership:

Manager Ownership = Shares owned by directors and commissioners / Outstanding Shares $\mathrm{x}$ $100 \%$. The quality of a manager in a company based on the manager's ability, if the manager's quality were good, they can manage the company. in contrast, when the manager's quality is low the manager's ability to manage the company is also low. The formula used uses the Demerjian [23] model as follows:
Firm efficiency= Sales $/(\mathrm{COGS}+\mathrm{SG} \& \mathrm{~A}+\mathrm{PPE}+\mathrm{R} \& \mathrm{D}+\mathrm{Goodwill}+$ Intangible Assets)

Total assets, market share, free cash flow, company age as company characteristics were are used to confounding variables on determining the quality of managers in the calculation model.

Firm Efficiency $=\alpha+\beta 1 " \quad$ "ln" " ("Total Asset" )" $+\beta 2$ " Market Share+ $\beta 3$ " Free Cash Flow Indicator " "i" ^ 』 "+ $\beta 4$ " ln" ("Age" )" $+\epsilon$

Market share calculated by comparing the sales of each company with the total revenue sector, The free cash indicator uses a dummy of 1 if the company has free cash flow in year $t$, The residual value $\varepsilon$ is an attribute for manager specific effects which is a measure of managerial ability.

Conservatism indicators in Indonesia bank reflected in the healthiness of a company derived from the CAMEL ratio, due to standards required on a bank that managed by the financial services authority. The health assessment calculated based on several financial ratios, The calculation from Veithzal [24]:

\begin{tabular}{|r|r|}
\hline CAR & $=$ Capital / Risk Weighted Assets x 100\% \\
\hline Productive Asset Quality & $=$ Earning assets classified / Total earning assets x 100\% \\
\hline Net Profit Margin & $=$ Net profit / Operating income x 100\% \\
\hline Return On Asset & $=$ Earning after tax / Total Assets x $100 \%$ \\
\hline BOPO & $=$ Operating Costs / Operating Income $\times 100 \%$ \\
\hline Loan to Deposit Ratio & $=$ Third party Credit / Funds x 100\% \\
\hline
\end{tabular}


Fazril Azi Nugraha \& Erna Setiany., Sch Bull, March 2020; 6(3): 76-82

Tabel-1: Bank health scoring

\begin{tabular}{|l|l|l|l|l|l|}
\hline No. & & \multicolumn{2}{|c|}{ Assessed Factors } & \multicolumn{1}{c|}{ Assessed Components } & Valuation (\%) \\
\hline 1 & & C & Capital & Capital to weighted assets & 25 \\
\hline 2 & & A & $\begin{array}{l}\text { Quality of } \\
\text { productive } \\
\text { activities }\end{array}$ & $\begin{array}{l}\text { The ratio of allowance for possible losses on earning } \\
\text { assets provided to allowance for earning assets that must } \\
\text { be established }\end{array}$ & 30 \\
\hline 3 & & M & Management & Net Profit Margin & 25 \\
\hline 4 & & E & Profitability & $\begin{array}{l}\bullet \text { ROE } \\
\text { Ratio of operating costs to operating income }\end{array}$ & 5 \\
\hline 5 & & L & Liquidity & $\begin{array}{l}\text { The ratio of the amount of credit given to funds received } \\
\text { by the bank }\end{array}$ & 10 \\
\hline
\end{tabular}

Notes: higher score indicates the degree of bank meets the standard, and also means the company has a high conservatism in the financial report

The data analysis method in this research is multiple linear analyses. Use the following model to explain the relationship of manager ownership, manager quality and conservatism to earnings quality:

\section{Model I:}

$\mathrm{DACC}=\beta 0+\beta 1$ Mshare $+\beta 2$ MQuality $+\beta 3$ Cons $+\mathrm{e}$ Model II:

$\mathrm{DACC}=\beta 0+\beta 1$ MShare $+\beta 2$ MQuality $+\beta 3$ Cons + $\beta 4 \mathrm{SG}+\beta 5 \mathrm{Lev}+\beta 6 \mathrm{FCF}+\mathrm{e}$

Furthermore, to ensure that the independent variable is not affected by several specific conditions of the company such as sales growth, leverage, and free cash flow. Then, three variables are added as a distort variable to see whether the presence variable will change the direction of the correlation of the independent variable to the dependent variable.

\section{RESULT AND DISCUSSION}

Based on the statistic software SPSS, the result of descriptive statistics are including: n, mean, standard deviation, minimum value and maximum value (See table 2)

Tabel-2: Descriptive Statistics

\begin{tabular}{|l|r|r|r|r|r|}
\hline \multicolumn{1}{|c|}{ Variabel } & N & \multicolumn{1}{c|}{ Mean } & $\begin{array}{c}\text { Std. } \\
\text { Deviation }\end{array}$ & \multicolumn{1}{c|}{ Min } & \multicolumn{1}{c|}{ Max } \\
\hline DACC & 218 & 2146173998 & 3128104595 & 7047078 & 15769162395 \\
\hline MShare & 218 & $1,4223 \%$ & $4,6242 \%$ & $0,00 \%$ & $28,30 \%$ \\
\hline MQuality & 218 &, 5622260 & 72,9068 & $-640,45034$ & 101,27209 \\
\hline Cons & 218 & 83 & 5,8451 & 46,09 & 95,98 \\
\hline SG & 218 &, 0733 &, 2792 & $-3,0695$ &, 8376 \\
\hline Lev & 218 & 2,2751 & 15,2445 &, 0045 & 163,4737 \\
\hline FCF & 218 & 1829535477 & 7763578059 & -32596059000 & 59811328000 \\
\hline
\end{tabular}

Based on the table above, that shows the lowest value of discretionary accruals is 7,047,078,533, then the highest value is $15,769,162,395,000$ with an average value of $2,146,173,998,000$ based on the data we can conclude the value of discretionary accrual is high that indicates there are earning management and we assumed that the earnings quality of the banking sector companies was low. Furthermore, managerial ownership ranges from $0 \%$ to $28 \%$ with an average ownership of $1.42 \%$ so that low managerial ownership in banking companies. The quality of managers with values ranging from -604 to 101 with an average of 0.5 indicates that the quality of managers is low. then the score of conservatism with values ranging from 46 to 95.98 with an average of 83 which means banking companies highly conservative which they get a high score through the standard.

Tabel-3: Result Model I

\begin{tabular}{|l|l|l|}
\hline \multicolumn{2}{|c|}{ Model I: DACC $=\boldsymbol{\beta 0}+\boldsymbol{\beta 1}$ Mshare $+\boldsymbol{\beta 2}$ MQuality $+\boldsymbol{\beta 3}$ Cons $+\mathbf{e}$} \\
\hline Variabel & Coefficients (B) & Sig. \\
\hline Mshare &,- 020 &, $027 * *$ \\
\hline Mquality &, 000 &, 582 \\
\hline Cons &,- 004 &, 543 \\
\hline & Notes: $*$ Significance at 1\%; \\
& $* *$ Significance at 5\%; \\
& $* * *$ Significance at 10\%
\end{tabular}


Tabel-4: Result Model II

\begin{tabular}{|c|c|c|}
\hline \multicolumn{3}{|c|}{ Model II: } \\
DACC $=\boldsymbol{\beta 0}+\boldsymbol{\beta 1}$ MShare $+\boldsymbol{\beta 2}$ MQuality $+\boldsymbol{\beta 3}$ Cons $+\boldsymbol{\beta 4} \mathbf{S G}+\boldsymbol{\beta 5} \mathbf{L e v}+\boldsymbol{\beta 6} \mathbf{F C F}+\mathbf{e}$ \\
\hline Variabel & Coefficients (B) & Sig. \\
\hline Mshare &,- 019 &, $043^{* *}$ \\
\hline Mquality &, 000467 &, 442 \\
\hline Cons &,- 005 &, 465 \\
\hline SG &,- 098 &, 533 \\
\hline Lev &, 000 &, 954 \\
\hline FCF & $1,335 \mathrm{E}-14$ &, $014^{* *}$ \\
\hline & & \\
\hline
\end{tabular}

Notes: * Significance at $1 \%$;

** Significance at $5 \%$;

$* * *$ Significance at $10 \%$

Based on the findings, it can be concluded that the results of both models. The result shows the independent variables and the dependent variable used in the study has consistent results both in significance and influence.

Manager ownership has a significant effect on earnings quality. The results are following Asri [12] and other studies, namely Khafid and Arief [14]. This shows that high managerial ownership can affect the process of preparing financial statements. A high concentration of ownership can be a mechanism for corporate governance in a manager-shareholder relationship, where an increase in share ownership by managers in the company will be able to create optimal company performance and motivate managers to act more carefully because they bear consequences of every action they do. Furthermore, Putra [6] describes governance mechanisms that can be used to align activities to suit the interests of company owners by involving managers in company ownership. Thus, for managers to run more responsible companies can be done by increasing the percentage of manager ownership. To improve the integrity of the report by increasing decision making and honesty in presenting financial information.

Managers become an important factor in determining and carrying out company operations. So that managers will show their ability to understand the outlook for prospects, industry and economic environment, which will then provide results on the company's operations that can be seen through financial statements to investors. On the other hand, the preparation of financial statements is governed by accounting standards, so that the chosen accounting method can affect the quality of the financial statements. The results show that manager quality does not significantly affect earnings quality in the Indonesian banking sector. Correlation of manager quality and earnings quality is negative, this study supports the research of Edi and Santi [25] who said that the ability of high managers will be inversely proportional to the quality of the company's accruals. It also explains that the results of earnings reports ie the quality of accruals produced can be determined by the ability of managers. The more qualified managers can increase the level of estimation of the accounting system to produce quality policies as well. Also, this study shows that managerial skills are closely related to low earnings quality through earnings management. Furthermore, Setin and Etty's research [15] found that more capable managers are involved in income management which leads to their valuable reputation and creates other incentives, besides that managers, will avoid too much income management. besides, managers who tend to be involved in earnings management rely more on accrual earnings management. Demerjian [23] also said that highly capable managers use their superior skills to report income streams to avoid various traps in reporting that can harm shareholders because intentional income smoothing is seen as a profitable activity by managers.

Based on the results of research conservatism does not affect earnings quality. According to Vtanparas [8] research, conservatism can improve earnings quality and reduce agency conflict. By choosing good conservative accounting methods, companies can change earnings quality by making changes in investment in operational assets, according to Twentina and Wirama [22]. discuss conservatism related to earnings information disclosed by the company but in some cases investors are protected from mistakes in evaluating earnings on the financial information presented not under the actual situation with conservatism. The conservatism policy carried out by management is allowed by standard setters not to violate the standard.

\section{CONCLUSIONS}

Based on the results of the study, the conclusions are as follows

- Manager ownership affects earnings quality in Indonesian banking companies. The high concentration of ownership can function as a mechanism of corporate governance in the manager-shareholder relationship. Where an 
increase in stock owned by managers in a company can lead to optimal company performance and motivates managers to act more cautiously in submitting their financial statements, this will increase their integrity and reduce earnings management practices because they will share the consequences of every action taken. done to improve the quality of earnings.

- Furthermore, the quality of managers does not significantly influence companies in the banking sector, this is due to the low efficiency of Indonesian banking companies, which is indicated by the low-quality score of managers based on comparison of output and input of company resources. Also, research shows that the quality of accrual earnings generated is determined by the ability of a manager to improve the quality of accounting policies and estimates in the accounting system. Besides, this study shows that managerial skills are closely related to earnings management practices that affect earnings information. But the manager's background for earnings management cannot be known.

- Conservatism is insignificant to the quality of earnings, this is due to the standard on banks in Indonesia which makes management more conservative in reporting financial statements. Conservatism related to the quality of earnings information protects investors from mistakes in evaluating earnings on financial information that is presented not under actual conditions and decreases accrual earnings. Besides, conservatism can reduce agency conflict, by choosing good conservative accounting methods, companies can change the quality of earnings by making changes in investment in operational assets.

\section{REFERENCES}

1. Scott, W. R. (2015). Financial accounting theory seventh edition. United States: Pearson.

2. Stephn, B. (2013). Theory and practice of corporate governance an integrated approach. New york: Cambridge university press

3. Dul, M. (2009). Faktor-Faktor yang mempengaruhi manajemen laba pada perusahaan perbankan di bursa efek Indonesia. Jurnal Dinamika Ekonomi dan Bisnis, 6(2), 121-136.

4. Ahmad, A. (2018). Earning Management in Banking Industry and its Impact on The Firm Value. AKRUAL: Jurnal Akuntansi, 10, 69-84.

5. Faradilla, A., \& Ari, D.C. (2013). Analisis Manajemen Laba pada Perbankan Syariah. Jurnal Reviu Akuntansi dan Keuangan, 4(1), 5774.

6. Daniel, S., Tawakal, P., \& Dul, M. (2012). Pengaruh Independensi, Mekanisme Corporate Governance, Kualitas Audit, dan Manajemen Laba terhadap Integritas Laporan Keuangan. Diponegoro journal of accounting, 1(2).
7. Anggraheni, N.S. (2010). Pengaruh mekanisme corporate governance terhadap nilai perusahaan dengan kualitas laba sebagai variabel intervening pada perusahaan manufaktur yang terdaftar di bursa efek Indonesia periode 2004-2007. Jurnal ekonomi dan bisnis, 4(3).

8. Yoga, A.N., \& Tresno, E.J. (2014). Pengaruh alokasi pajak antar periode, investment opportunity set dan likuiditas terhadap kualitas laba. Jurnal ilmiah wahana akuntansi, 109. 9(2).

9. Setiany, E., Purwanto, P., Suhardjanto. D. (2018). Corporate Governance and Financial Performance: A Comparative Study of South East Asia's Hospitality Industries. Review of Integrative Business and Economics Research, $7(2)$

10. Hamonangan, S., \& Mas'ud, M. (2006). Mekanisme Corporate Governance, Kualitas Laba dan Nilai Perusahaan. Simposium Nasional Akuntansi 9 Padang.

11. Muhammad, N.H., Tony, V.Z., Keita, D., A.K.M. Waresul Karim. (2016). Does Corporate Governance affect Earnings Quality: Evidence from an Emerging Market? SSRN: http://ssrn.com/abstract=1726134.

12. Marselinus, A. (2017). The effect ownership structure on earning quality (empirical study of manufacturing companies listed on Indonesia stock. SSRN: https://ssrn.com/abstract=3000190.

13. Wafa, M.A., \& Younes, B. (2014). The relationship between ownership structure and earnings quality in the French. International journal of accounting and economics studies, 2(2), 80-87.

14. Peter, R.D., Melissa Lewis-Western., Sarah McVay. (2017). How do intentional earnings smoothing vary with managerial ability? Journal of Accounting, Auditing \& Finance, 35(2), 406437.

15. Setin \& Etty, M. (2018). The effect of Managerial Ability towards Earning Quality with Audit Committee as Moderating Variable. Journal of Business and Retail Management Research (JBRMR), 12(3).

16. Weitzu, C., \& Chia-Wei Tai. (2015). The effect of managerial ability on earnings quality in the pre and post ifrs adoption periods. Proceedings of the third middle-east conference on global business, economics, finance and banking, Dubai, October.

17. García-Meca, E., \& García-Sánchez, I. M. (2018). Does managerial ability influence the quality of financial reporting? European Management Journal, 36(4), 544-557.

18. Sofiasani, G., \& Gautama, B. P. (2016). Pengaruh CAMEL Terhadap Financial Distress Pada Sektor Perbankan Indonesia Periode 2009. 2013. Journal of Business Management Education (JBME), 1(1), 138-148. 
19. Harnovinsah \& Ahmad, K.J. (2018). Pengaruh Faktor Keuangan dan Intensitas Aset Tetap Terhadap Keputusan Pelaporan Keuangan dan Pajak. Jurnal Tekun, 8(1).

20. Veronica, E. (2013). Analisis Pengaruh Konservatisme Akuntansi Terhadap Kualitas Laba Akrual Yang Dimoderasi Oleh Good Corporate Governance Pada LQ 45 Di Bursa Efek Indonesia (BEI). Jurnal Audit dan Akuntansi Fakultas Ekonomi (JAAKFE), 2(1).

21. Vatanparast, M., Baqerian, J. M., \& Hassanzade, M. (2014). The Relationship between Conservatism and Earnings Quality in Tehran Stock Exchange. Indian Journal of Fundamental and Applied Life Sciences, 4(1), 1417-1425.
22. Tuwentina, P., \& Wirama, D. G. (2014). Pengaruh konservatisme akuntansi dan good corporate governance pada kualitas laba. EJurnal Akuntansi, 185-201.

23. Demerjian, P., Lev, B., \& McVay, S. (2012). Quantifying managerial ability: A new measure and validity tests. Management science, 58(7), 1229-1248.

24. Rivai, V. (2016). Manajemen sumber daya manusia untuk perusahaan.

25. Edi, E., \& Yopie, S. (2019). Management Capability To Produce Quality Earning. Jurnal Reviu Akuntansi dan Keuangan, 9(1), 75-84. 